\title{
Influence of Accounting Balance Indicators on Investment Evaluation
}

\author{
Levan Sabauri ${ }^{1}$ \\ ${ }^{1}$ Faculty of Economics and Business, Iv. Javakhishvili Tbilisi State University, Tbiilsi, Georgia \\ Correspondence: Levan Sabauri, Faculty of Economics and Business, Iv. Javakhishvili Tbilisi State University, Tbiilsi, \\ Georgia.
}

Received: October 21, 2015

Accepted: November 4, 2015

Available online: November 17, 2015

doi:10.11114/afa.v2i1.1158

URL: http://dx.doi.org/10.11114/afa.v2i1.1158

\begin{abstract}
The work considers essential matters of cash flow return on investments. The basic of CFROI ${ }^{\circledR}$ methodology is the idea of a company as the integrity of projects. Those projects have different moments and terms of development and effect as well as the various rates of payback. Subject to the goals of the analysis, they are represented as a single consolidated project, which generates cash flows within the term of useful life of those assets to which the investments are aimed.

The CFROI $^{\circledR}$ is based on the main idea - to determine the inflation-adjusted cash flows in favor of every capital owner and to compare them with the inflation-adjusted historical investments which have been put in the business in consideration of the depreciated cost of non-depreciable assets according to the internal rate.
\end{abstract}

The work focuses on the detailed analysis of the $\mathrm{CFROI}^{\circledR}$ components. All components are considered separately and in connection with each other that makes the single chain determining the cash rate of return on investments. Within the analysis of cash rate of return on investments it is important to determine the duration of life cycle of strategic investments that is directly related to the establishment of the average age of the fixed depreciated tangible assets. When determining the average asset age noteworthy is by what formula it will be calculated.

Based on the practical examples the work presents the cases of "artificial rejuvenation" of depreciated assets and "artificial aging" of assets.

The work also determines the values of total investments and total cash flows, their effect on calculation of the cash rate of return on investments. Parallel with investments and cash flows there is also considered the role of IRR and MIRR for calculation of CFROI. Together with the investment model of calculation there has been applied calculation with CFROI coefficient which is based on the use of data of the economical depreciation of total investments.

Therefore, the operating cash flows are recurrent and reiterated and they create the necessary idea of the profit to be received from a business in future. $\mathrm{CFROI}^{\circledR}$ value is measured on the annual basis. It may be subject to modification. Noteworthy is to determine the internal rate of return (IRR) of a business in the current conditions. $\mathrm{CFROI}^{\circledR}$ is of analytical predictable nature. However, it shall be applied with a particular caution.

In the final analysis, the purport of the company existence is to return all investments deposited in it and to receive the adequate revenue which will compensate alternative expenses and bring profit to the company.

Keywords: CFROI ${ }^{\circledR}$, net present Value, internal rate of return, weighted average cost of capital, depreciable assets, assets life

\section{Firm - Portfolio Project}

Basis of CFROI ${ }^{\circledR 1}$ methodology is the concept of a firm as the collection of projects. These projects have different instants and life of operation as well as different levels of profitability. For the purposes of analysis, they are represented as one cumulative project providing generation of cash flows during the useful life of assets, towards which the investment are directed.

If we discuss the firm in terms of investment projects, then regular assessment of their effectiveness shall be conducted by using such indices as $\mathrm{NPV}^{2}$ and $\mathrm{IRR}^{3}$. Only such accounting features as profitability and economic efficiency

\footnotetext{
${ }^{1}$ CFROI $^{\circledR}$ - Cash Flow Return on Investment

2 NPV- Net Present Value

3 IRR - Internal Rate of Return
} 
cannot express complete success achieved in implementation of such aggregated projects. The only problem is that we don't have any information on the investments made and cash flows but this problem can be solved through relatively mild transformation of financial statement highlights.

Based on profit and loss statement, the data on cash flows generated from investment projects portfolio can be obtained, and the balance sheet may provide more or less precise values of investments made in this portfolio. In general, this is all what is necessary for investment analysis. Thereafter, NPV, IRR, MIRR ${ }^{4}$ and etc. can be calculated. The only problem is to define the discount and reinvestment rates. Usually, WACC ${ }^{5}$ - weighted average cost of capital $[1 ; 3]$ assumes the role thereof.

\section{CFROI $^{\circledR}$}

$\mathrm{CFROI}^{\circledR}$ indicator is based on financial theory hypothesis that mostly the capital market estimates the company's ability to provide cash flow generation and represents a peculiar internal norm of profitability, which is adapted to evaluate the investments made in the company. It was worked out by HOLT Value Associates.

CFROI $^{\circledR}$ is based on the basic idea - to identify the cash flows adjusted for inflation in favor of all capital owners and compare them to those historical investments adjusted for inflation, which were made in business through internal norm of profitability, considering the residual value of non-depreciable assets.

CFROI ${ }^{\circledR}$ model consists of four components:

1) GI - Gross investment

2) GCF - Gross Cash Flow

3) Non - Depreciable Assets

4) Assets Life

There are two main methods of $\mathrm{CFROI}^{\circledR}$ calculation (they will be discussed below) and both methods apply the above-mentioned components.

CFROI ${ }^{\circledR}$ calculation stages:

1) Accounting data through adjustment will be transformed into economic concepts. The above-mentioned four components will be determined. They will embody the investment cash flows.

2) Based on the values obtained, the internal rate of return (IRR or adjusted IRR) will be determined.

Now, let's discuss the calculation details of the above-mentioned model components.

\section{Gross Investment}

Gross investment is the company's contribution to assets in the very investment projects portfolio, which we have just discussed above. The gross investment value shall be determined by the sum of net asset value and accumulated depreciation. In addition, the obtained adjusted economic value shall increase by the inflation rate applicable upon the moment of asset formation. So, this is the way to define the value of capital invested for the entire existence of the company.

The assets' value shown on the balance sheet shall be deducted non-debt liabilities. The "debt" and "liabilities" concepts are unambiguous. Debt is the funds borrowed, and liabilities are defined as future "sacrifices" of economic benefits that the entity is presently obliged to make to other entities. Liabilities arise due to the operations and events occurred in the past.

Non-debt contingent liabilities are the liabilities arisen due to the reasons other than the loans, for instance, liabilities imposed by court actions, warranty liabilities, liabilities for environmental damage. Non-debt current liabilities usually are represented by accounts payable and accruals.

From an economic point of view, investments consist of tangible and intangible assets. Intangible assets, first of all, include goodwill. Since goodwill undergoes annual impairment testing in accordance with US GAAP ${ }^{6}$ and IFRS ${ }^{7}$, the balance sheet value thereof may be less than its historical value. In order to obtain the investment value of goodwill, the goodwill impairment shall be restored for a definite period in the past. Annual impairment test is required to establish the fair value of capital invested in business; however, restoration of impairment shall apply to long-term physical assets as well.

\footnotetext{
${ }^{4}$ MIRR - Modified Internal Rate of Return

5 WACC - Weighted Average Cost of Capital

${ }^{6}$ US GAAP - Generally Accepted Accounting Principles of the United States

7 IFRS - International Financial Reporting Standards
} 
Furthermore, it is required to capitalize the amount of scientific research and pilot design works (hereinafter the R\&D) on dynamics or within at least five years since depreciation of such works usually occurs during this time period, however, this is the matter of managerial accounting policy adopted within the organization. Other expenses, which are realized not only during the current period but also for a long period of time, may be also capitalized (expenses related to advertisement, studies and etc.). Listed above is only a small part of adjustments that may be applied to the accounting provisions. Any adjustment applied at $\mathrm{EVA}^{8}$ calculation shall be appropriate, namely, adjustment of deferred taxes, pension obligations and inventory accounting methods (if LIFO $^{9}$ is applied), elimination of profit and loss through assets ownership, removal of distorting revaluation effects, capitalization of reorganization expenses.

Only after elimination of current accounting errors we can be sure that the cash flow values of invested capital and operating income are found, which allows formation of profitable company or determination of actual state of the same company's failure. In addition, the adjustment must not be misused. Each adjustment must be imbued with common sense and applied systematically. Otherwise, doubts may appear on purposeful manipulation of indicators.

\subsection{Adjustment for Inflation}

Gross investment value must be brought into line with current-period prices. Book value of assets increases in consideration of the inflation rate occurred upon the moment of purchase of such assets.

It should be taken into account that adjustment for inflation is necessary not only to identify the exact value of assets by the moment of assets evaluation but to determine the value of the capital that the investors failed to come up with at the moment of capitalization [6]. Therefore, it is necessary to know the current purchasing power thereof. If we evaluate investment based on the prices applicable ten years ago and express the operating cash flow in current prices, the indicators will be inconsistent and this will promptly affect the results of analysis. All value indices must be evaluated based on current prices.

\section{Fixed Assets (Gross Plant)}

Gross plant is the central part of gross investment. Property Plant \& Equipment (PP\&E) ${ }^{10}$ are the fixed assets to be adjusted to current prices in the first place. Furthermore, the adjusted gross plant may be also included in calculation. Non-depreciable long-term assets (land areas) shall be excluded from gross plant. They shall be included in liquidation value of business. Gross plant doesn't entail intangible assets, goodwill, capitalized leasing and capitalized costs of R\&D. The concept of gross plant applies against non-depreciable assets, denotes the total value of depreciable assets integrating buildings and industrial equipment. In order to calculate gross plant, the land areas, land improvement costs (such calculation may lead to increase and capitalization of land value) and construction in progress ${ }^{11}$ must be excluded from the accounting article Property Plant \& Equipment (PP\&E).

Adjusted Gross Plant $=$ Gross Property Plant \& Equipment $(\mathrm{PP} \& \mathrm{E})-$ Land \& Improvements -

Construction in Progress.

\subsection{Asset Life}

Fixed assets are purchased at different times, and the operation life thereof differs. Therefore, the asset life, usually as the average value, shall be determined in a simplified manner. Adjusted Gross Plant shall be divided by Annual Depreciation, Depletion and Amortization (DDA) Expense [9]:

$$
\text { Asset Life }=\text { Adjusted Gross Plant / DDA Expense. }
$$

Of course, the result of such operation creates only general impression of business lifecycle. Presumably, it may differ from reality as the used assets are replaced with new ones at the expense of depreciation fund. But the use of depreciation funds within $\mathrm{CFROI}^{\circledR}$ cash flow methodology is considered for replacement of assets as a new investment, in other words, the asset life implies the period during which they will generate cash flow until full depreciation thereof.

Asset life can be calculated by adding the asset age available at the moment and the period of the remaining life of assets:

$$
\text { Asset Life }=\text { Asset Age }+ \text { Remaining Life of Assets }
$$

In addition, the asset age shall be calculated by correlation of the accumulated depreciation with the value of annual

\footnotetext{
${ }^{8}$ EVA - Economic Value Added

${ }^{9}$ LIFO - Last In First Out

${ }^{10}$ Property Plant \& Equipment (PP\&E) - the American or European balance sheet article; this accounting article (PP\&E) implies Land, Building and Machinery and Equipment.

${ }^{11}$ Objects under construction do not participate in the operating activity and thus, the value thereof must be excluded from gross investment. In addition, they cannot earn profit yet and thus, no depreciation must be charged, therefore, they belong to non-depreciable assets.
} 
depreciation expense, and the remained operation life shall be calculated by correlation of the book value of depreciable assets with the value of annual depreciation expense.

Both alternatives must give approximately one and the same result as the adjusted value of depreciable assets include the book value thereof and accumulated depreciation, in other words, these are two alternatives of one formula. Difference may arise only due to asymmetric use of adjustment. The asset maintenance service life shall be determined upon making investment until full amortization thereof.

\section{Strategic Investment Lifecycle}

The life (duration) of strategic investment maintenance shall be established by different methods, which depends on peculiarity of a particular business and applied strategic guidelines. It should not be hastily determined. This is the subject of detailed and thorough analysis. In mining enterprises the investment lifecycle starts upon commencement of mine works and ends after depletion of natural resource reserves. Duration of deposit exploitation depends on resource reserves studied and extraction rates. Until now these values haven't been fully determined.

Duration of the enterprise performance in most cases may be connected with the estimated period of strategic gross plant operation, full depreciation of which will make it impossible to further continue business. In capital-capacious industries the restoration of gross plant only through depreciation charges may become problematic due to high cost of equipment. In order to solve the problems caused by tear-and-wear, new investments are to be made, which by the scale and significance may be compared to primary strategic funds. They may be directed at complete replacement of equipment, technical and technological rearmament, construction of new plants, launch of new capacities and etc.

Coming in a new market, founding of new branches, launch of new production lines are typical examples of strategic solutions. Accounting criteria don't allow giving clear classification of the company's assets into strategic and supporting investment. Strategic investment shall be evaluated independently as the generating assets. We think that such approach is not a particular difficulty; however, it can be applied only if a clear understanding is developed of the profit earned from the assets capable of generation.

Current assets, as mentioned above several times, are not themselves investments. Only the circulating capital can be deemed investment as it is used during one year and makes almost no influence on the investment maintenance service life.

As already noted, the assets maintenance service life is often determined in a simplified manner: Adjusted Gross Plant is divided by Annual Depreciation, Depletion \& Amortization (DDA) Expense:

$$
\text { Assets Life }=\text { Adjusted Gross Plant } / \text { Annual DDA Expenses }
$$

In the first place, different business fields mostly are based on tangible or intangible assets, or even on economic life of R\&D. For example, in computer and software business tangible assets tell us nothing about how a company may maintain viability in a competitive environment. All in all, a company's success and capability depends on the expected life of patents and competitive advantages under R\&D, new inventions and technologies. As soon as the computer generation is changed, the hardware must be changed as well. In such cases, it is logical to calculate the hardware service life based on the service life of intangible assets and/or depreciation thereof, and the service life of their competitive advantages. Calculation shall be as reasonable and correct as possible and shall consider all possible disturbing cases.

In the second place, the basic assets shall be taken into consideration after they are added with accumulation depreciation; however, this shall be effected before adjustment for inflation as the depreciation expenses are accrued on historical value of the given assets. Application of the formula after adjustment for inflation may strongly increase the useful life of assets.

In the third place, all non-depreciable articles shall be excluded from the basic assets as they affect unjustified increase of service life of equipment and facilities.

\section{Average Age of Assets}

In order to provide gross capital adjustment for inflation, we should know the age of gross basic assets. It is not easy to determine the precise age of fixed depreciable tangible assets as no registration is held in this term; however, approximate evaluations can be obtained. Since the current assets are purchased and used during one year, they may be ignored. We should only know the age of fixed (non-circulating) assets. The easiest and maybe the only simple rule to establish the same is as follows - the accumulated depreciation divided by the current depreciation expense [6]:

$$
\text { Asset Age }=\frac{\text { AccumulatedDepreciation }}{\text { CurrentDepreciationExpense }} \text {. }
$$


It is clear that the obtained value may be approximate. If there are no special problems with regard to accumulated depreciation (depreciation accumulated as per past and fully depreciated assets reduces at the write-off), the current depreciation expenses require more caution. This may be the reason of excessive rejuvenation or excessive aging of assets. Effects thereof are directed not only at denominator but at numerator as well. Accumulated depreciation is nothing else but the sum of past depreciation expenses as per basic assets still to be written-off. Here the differences in approximate service lives of old and new equipment, premises and facilities play crucial role. The thing is that depreciation expenses may be the result of high-cost and small-service-life fixed assets purchased not so long ago. Merging of long operation life of new equipment with short operation life of old equipment, if compared to real value, will lead us to the increase of calculated asset age, which will cause artificial aging of assets. Merger of long operation life of old equipment with short operation life of new equipment, on the contrary, will lead us to the reduction of calculated asset age, which will cause artificial rejuvenation of assets. Attention shall be also devoted to the share of young assets. The younger is the asset the less service life it has, but such influence may have considerably less effect on operation life. Exactly the young assets affect the value of depreciation expenses.

Table N1 provides the age structure of assets and real value of average age, also the calculated asset age obtained on the basis of the above discussed accounting formula. Finally, assets may turn out younger as the operation life of young assets is considerably short, subject to which the depreciation value is increased.

Table 1. Artificial rejuvenation of assets

\begin{tabular}{lcccccc}
\hline \multicolumn{1}{c}{ Age } & $\mathbf{9}$ & $\mathbf{7}$ & $\mathbf{2}$ & 1 & Total & $\begin{array}{c}\text { Calculated } \\
\text { service life }\end{array}$ \\
\hline $\begin{array}{l}\text { Initial value (one thousand Lari) } \\
\text { Useful service life (year) }\end{array}$ & 5000 & 2000 & 1000 & 500 & 8500 & \\
$\begin{array}{l}\text { Accumulated depreciation (one thousand } \\
\text { Lari) }\end{array}$ & 20 & 20 & 5 & 5 & & \\
$\begin{array}{l}\text { Depreciation expenses, linear method (one } \\
\text { thousand Lari) }\end{array}$ & 250 & 100 & 400 & 100 & 3450 & \\
$\begin{array}{l}\text { Residual value (one thousand Lari) } \\
\text { Share of assets as per the initial value (\%) }\end{array}$ & 2750 & 1300 & 600 & 100 & 650 & \\
$\begin{array}{l}\text { Share of assets as per book value (\%) } \\
\text { Average asset age (year) }\end{array}$ & 54 & 24 & 12 & 6 & 5050 & 5,31 \\
\hline
\end{tabular}

Table 2. Artificial aging of assets

\begin{tabular}{|c|c|c|c|c|c|c|}
\hline Age & 9 & 7 & 2 & 1 & Total & $\begin{array}{l}\text { Calculated } \\
\text { service life }\end{array}$ \\
\hline Initial value (one thousand Lari) & 5000 & 2000 & 1000 & 500 & 8500 & \\
\hline Useful service life (year) & 10 & 10 & 50 & 50 & & \\
\hline $\begin{array}{l}\text { Accumulated depreciation (one thousand } \\
\text { Lari) }\end{array}$ & 4500 & 1400 & 40 & 10 & 5950 & \\
\hline $\begin{array}{l}\text { Depreciation expenses, linear method (one } \\
\text { thousand Lari) }\end{array}$ & 500 & 200 & 20 & 10 & 730 & \\
\hline Residual value (one thousand Lari) & 500 & 600 & 960 & 490 & 2550 & 5,15 \\
\hline Share of assets as per the initial value (\%) & 59 & 24 & 12 & 6 & 100 & \\
\hline Share of assets as per book value $(\%)$ & 20 & 24 & 38 & 19 & 100 & \\
\hline Average asset age (year) & 1,8 & 1,6 & 0,8 & 0,2 & 4,4 & \\
\hline
\end{tabular}

Table 2. Provides the inverted situation. Assets are twice older than the obsolete assets being in operation for smaller period.

As a result of such errors, adjustment for inflation may have disastrous impact on the company efficiency assessment.

Example: if we use the data of the above formula and "UCNOBI" LTD statements, by the end of 2010 the average age of "UCNOBI" assets would make approximately 11,8 years (2172028/183577 Lari). Book value of the limited liability company's fixed assets would make 3490477 Lari by the end of 2010. In such a case, is adjustment for inflation needed? Since the assets are expressed in real value on the balance sheet, there's no need to provide adjustment for inflation. The problem is that assets devaluation is permanently tested. In this connection it is virtually impossible to determine the initial values of invested funds. However, devaluations, as a rule, are insignificant (inessential).

Gross calculated asset value along with the accumulated depreciation makes 5662505 Lari. This amount of fixed assets fully includes the depreciated but operating fixed assets, total value of which as of 31 December 2010 made 8731294 
Lari.

According to the above formula, (through depreciation) only the age of depreciable assets can be calculated. The age of non-depreciable fixed assets can be determined only according to internal information. If the share of non-depreciable fixed assets is not large, their age may be ignored. But what if non-depreciable assets are the basis of company's property? In such case, it is not advisable to determine their age by the above methods. Adjustment of book value of long-term non-depreciable assets for inflation is better to be provided separately and by the use of data on the purchase dates. Final average age of gross assets shall be determined in consideration of depreciable and non-depreciable asset structure and age:

$$
\text { Asset Age }=\frac{\text { non }- \text { deprFA }}{F A} \times \text { non-deprFAAge }+\frac{\text { GrossPlant }}{F A} \times \text { GrossPlantAge. }
$$

\section{Non-Depreciable Assets}

This is the part of gross investment, which wears out over the time. At the end of investment operation life, non-depreciable assets may be sold. Therefore, at the analysis of investment activity the residual value of such assets must not be ignored. The residual value may be quite high. Non-depreciable assets include the land parcels owned by company. According to the accounting rules, depreciation on such assets shall not be charged. Furthermore, in $\mathrm{CFROI}^{\circledR}$ model non-depreciable assets include also the cash assets, accounts receivable (other than the bad requirements) and inventory:

$$
\begin{gathered}
\text { Non }- \text { Depreciating Assets }=\text { Current Assets }- \text { Current Liabilities }+ \\
\text { Gross Land }+ \text { Other Long }- \text { Term Assets }
\end{gathered}
$$

\subsection{Residual Asset Value}

Salvage asset value equals non-depreciable asset value as theoretically they are maintained unchanged at the end of asset operation life and may be sold. This of course is a very simple understanding. In the first place, the non-depreciable asset prices may be changed. In any case, it would be advisable to consider established trends in the dynamics of price changes on immovable property and land parcels. In the second place, we face certain problems with regard to storage of cash facilities and tangible assets. Cash facilities, of course, cannot be depreciated but they may be spent at any time. And the tangible asset prices are more variable than the land parcel prices. Within the scope of $\mathrm{CFROI}^{\circledR}$ methodology, such assumption is applicable that at the end of depreciable asset service life all non-depreciable assets shall be sold as per their current value and shall make the last (liquidation) cash flow.

We have to make another specification: at the end of asset lifecycle, the business salvage value may be positive or negative. Part of the property may be sold and real monetary compensation may be received as per the residual value. However, liquidation of some enterprises may be accompanied with serious expenditure related to asset liquidation, which are dictated by both environmental and social considerations. Such expenditure may be inevitable as execution thereof is prescribed by laws. Therefore, calculations shall consider the circumstances that may occur at closing of business. It's very difficult to forecast what the enterprise assets will cost after several decades. Usually, the data of salvage value of fixed assets may be applied, which are determined by accountants when recording them on the balance sheet.

\section{Calculation of Gross Investment}

Let's summarize everything related to calculation of gross investment.

Gross investment shall be defined as the sum of capitalized values of non-depreciable assets, accumulated depreciation, total value of all enterprise depreciable assets, and all expenditure incurred in the past and current periods for capitalized operating leasing and R\&D during the entire alleged period of utilization of assets leased as per applicable interest rate, minus current non-debt liabilities:

Gross Investment $(\mathrm{GI})=$ Net Asset Value + Accumulated Depreciation on Asset + Accumulated Goodwill

Impairments + Capitalized R\&D + Capitalized Operating Leasing + Current Dollar Adjustment.

More complicated alternative is as follows:

\section{Gross invested Capital}




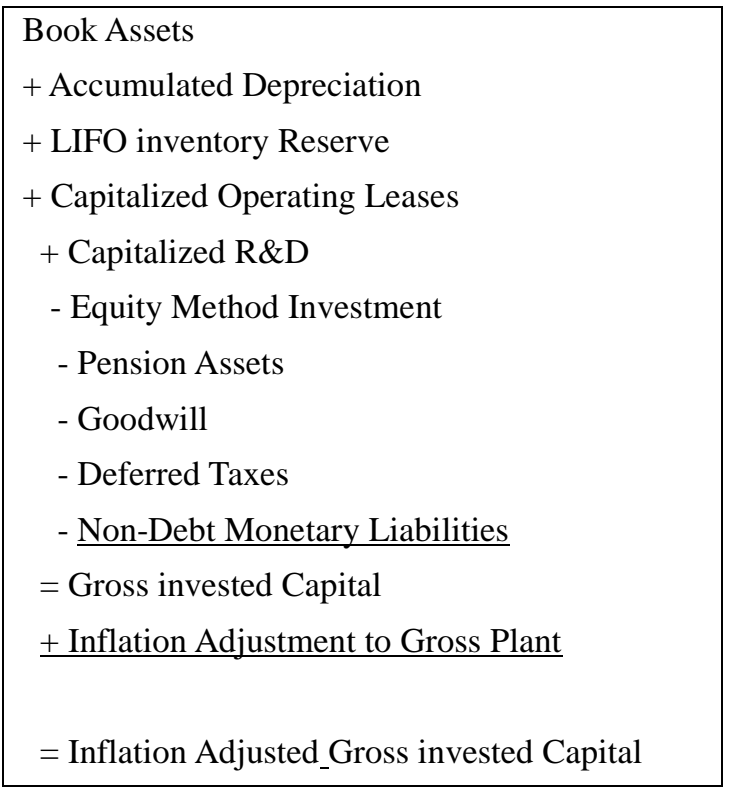

After all these calculations, the gross investment value shall be brought into line with applicable prices (adjustment for inflation).

Adjustment for inflation and a number of other calculations are arbitrary assessments, which reduces the level of confidence in the results.

Example: Calculation of gross investment. Let's discuss the company, the average asset age of which makes seven years. Its net asset value makes 300000 Lari. Asset operation life includes 15 years. Assets of 120000 Lari are non-depreciable. Accumulated depreciation during seven years upon incorporation of the company made 75000 Lari.

In addition, the assets used for operating leasing are recorded off the balance sheet. Duration of leasing agreements makes five years. Lease payments value equals 15000 Lari. Inflation for the past period is represented in Table N3. Inflation factor is calculated by multiplication of temporary values of those indicators that have been formed during the period from asset formation until conduction of assessments.

Table 3.

\begin{tabular}{lccccccc}
\hline \multicolumn{1}{c}{ Years } & $\mathbf{2 0 0 0}$ & $\mathbf{2 0 0 1}$ & $\mathbf{2 0 0 2}$ & $\mathbf{2 0 0 3}$ & $\mathbf{2 0 0 4}$ & $\mathbf{2 0 0 5}$ & $\mathbf{2 0 0 6}$ \\
\hline Inflation indicator against the previous year (for & & & & & & & \\
industrial goods manufacturers) & 1,319 & 1,083 & 1,177 & 1,125 & 1,288 & 1,134 & 1,104 \\
Total inflation indicator during 7 years & - & - & - & - & - & - & 3,050003 \\
\hline
\end{tabular}

Gross investment may be determined according to the following scheme:

$\mathrm{GI}=(300000+75000) \times 3,050003=1143751$ Lari

Investment start date in the company may have taken place in the distant past. Determination of adjustment for inflation is not a difficulty for a young company but how to behave when business is 20, 50 or 100 years old? In such case, the adjustment for inflation may take us far away.

In addition, it's rational to consider only essential and current investments in business development, where among the oldest investment shall be determined by the age of those assets through which the system was set up. However, many investments from the old ones may have lost effectiveness and have expired useful life. In such case, the age of technological equipment, facilities and premises shall be studied and their value shall be determined by the sale price.

\section{Gross Cash Flow}

Gross cash flow includes the annual cash assets flow from the main activity. Such cash flow can be obtained permanently for the period of operation of assets and evaluation of gross cash flow.

Gross cash flow shall be determined as the net cash flow from operating activities after deduction. Cash flow from financial activities mustn't be included.

Gross cash flow shall be calculated on the basis of net or operating profit, which shall include the depreciation expense for the given period, other non-monetary costs, operating lease expense. It is also admitted to deduct non-operating income (excluding profits tax). At calculation on the basis of company's net profit, where the pension schemes with fixed payables are used (in other words, when the company is responsible for the pensions granted to its former 
employees), the profit shall be also added with the pension costs and deducted the pension service costs. At calculation the effective interest rate shall be applied:

Gross Cash Flow $=$ Net Income + DDA + Interest Expense $=$ Rental Expense + Pension Costs - Pension Service Cost + Minority Interest - Gain on Special Items (after tax),

Or:

\begin{tabular}{l}
\hline \multicolumn{1}{c}{ Gross Cash Flow } \\
\hline Net Income \\
+ Extraordinary Items \\
- Special Items After Tax \\
+ Interest Expense \\
+ R\&D Expense \\
+ Rental Expense \\
+ Minority Interest Expense \\
+ Net Pension Cash Flow Adjustment \\
+ LIFO charge to FIFO Inventory \\
+ Monetary Holding Gain/Loss \\
- Equity Method Investment Income \\
= Gross Cash Flow
\end{tabular}

\section{Calculation of CFROI ${ }^{\circledR}$}

$\mathrm{CFROI}^{\circledR}$ shall be calculated as the internal rate of return (IRR) on the cash flow scheme, where gross investment is made at the initial stage, and gross cash flow is added with salvage value of assets (Table N4) [3;5;8]. As is known, there is no formula for calculation of IRR. Calculation shall be usually provided in Excel by BSD support.

Table 4. Final table for CFROI ${ }^{\circledR}$ calculation (Investment Model)

\begin{tabular}{|c|c|c|c|c|}
\hline Time Period & Gross Investment & Gross Cash Flow & $\begin{array}{c}\text { Business Salvage } \\
\text { Value }\end{array}$ & Cash Flow Scheme \\
\hline 0 & GI & & & GI \\
\hline 1 & & GCF & & GCF \\
\hline 2 & & GCF & & GCF \\
\hline$\ldots$ & & GCF & & GCF \\
\hline $\mathrm{n}$ & & GCF & SV & $\mathrm{GCF}+\mathrm{SV}$ \\
\hline $\mathrm{CFROI}^{\circledR}$ & & & & $\operatorname{IRR}\left(\sum^{n} C F_{i}\right)$ \\
\hline
\end{tabular}

\section{IRR problem}

Lately, the distrust of IRR has increased. We may think that the defects of IRR may be also peculiar to CFROI® but this is not true. CFROI ${ }^{\circledR}$ model is characterized by constant cash flow allowance, and the main defects of IRR are caused by the set of profitability values arisen in case of non-permanent cash flows with variable features. Thus, the given problems don't concern the $\mathrm{CFROI}^{\circledR}$ model.

The matter of cash flow reinvestment shall be considered more carefully. The thing is that IRR implicitly includes that interim cash flows are reinvested again in the project and cause to collect revenue equal to IRR. Actually, the rate according to which the project cash flows are reinvested may differ from the project internal rate of return, especially when this latter is too high or too low.

But it still does not give us the basis to lose hope. The IRR followers may breathe freely as the problem of gross cash flow reinvestment is subject to solving. CFROI ${ }^{\circledR}$ may be also calculated as MIRR (Modified Internal Rate of Return). Usually, the capital value shall be obtained from the project as the rate of positive interim cash flow reinvestment. Negative interim cash flows (outflows) are discounted by the financing rate ("safe" rate) and shall be discussed as the part of initial investment. Accordingly, MIRR will eliminate all the known defects of IRR. In addition, separation of 
financing and reinvestment rates is the achievement itself. Financing rate is the value of the firm's capital. It is understood that all negative cash outflows shall be compensated in consideration of this rate. Reinvestment rate, in fact, may be higher or lower than financing rate. Average or marginal rate of corporate investment profitability may be applied, for instance, as the reinvestment rate. Unless cash outflows are invested, we may plan reinvestment equal to zero. In this sense, MIRR allows to take all the essential nuances into account and considerably expand the possibilities of analysis. Calculation of MIRR can be by the following formula:

$$
M I R R=\sqrt[n]{\frac{\sum_{t=1}^{n} \operatorname{CashInf}_{t} \cdot(1+r)^{n-t}}{\sum_{t=0}^{n} \frac{\operatorname{CashOut}_{t}}{(1+f)^{t}}}}-1
$$

In theory, it is more accurate determination of profitability as in reality cash flows are reinvested on the basis of ordinary business profitability or at the level of capital value and not according to internal rate of return.

\section{CFROI ${ }^{\circledR}$ Calculation of Coefficient}

The CFROI ${ }^{\circledR}$ value shall be also easily calculated by use of the data on economic depreciation of gross investment. Moreover, economic depreciation implies constant cash flow, which allows compensating the value of assets applied at the expiration of the project lifecycle (strategic investments made in business). The above current value of cash flow shall equal the current value of gross depreciated investment by the end of strategic investment lifecycle [2], in other words, equality must be performed:

$$
\text { PV of the Replacement Cost of the Assets = PV of Economic Depreciation }
$$

$$
\frac{\text { GrossPlant }}{(1+r)^{n}}=\frac{\text { EconomicDepriciation }}{r} \times\left(1-\frac{1}{(1+r)^{n}}\right) .
$$

Wherefrom,

$$
\text { Economic Depreciation }=\frac{\text { GrossPlantxr }}{(1+r)^{n}-1} .
$$

Such linear form of economic depreciation is obtained because the constancy of gross cash flow is allowed. The formula shall apply the value of fixed depreciated assets (Gross Plant) adjusted for inflation in order to involve depreciation in current prices.

Suppose that the gross investment makes 470 million USD, the residual value of assets equals 120 million USD, gross depreciated assets total 210 million USD. Remained useful service life of assets makes 15 years. The age of assets is 7 years, and the capital value $-7 \%$. Accordingly, the economic depreciation makes:

$$
\mathrm{ED}=\frac{210 \cdot 0,07}{1,07^{22}-1}=4,3
$$

CFROI $^{\circledR}$ shall be calculated by the formula:

$$
\text { CFROI }^{\circledR}=\frac{\text { GrossCashFlow }- \text { EconomicDepreciation }}{\text { GrosInvestment }} .
$$

Furthermore, the formula results in the MIRR variety as the cash flow reinvestment is discussed according to the 
discount rate used for calculation of economic depreciation (usually, this is the average weighted value of capital).

$\mathrm{CFROI}^{\circledR}$ ratio version is remarkable that it allows the possibility to calculate negative results. IRR cannot be determined in case of negative operating cash flows. In addition, the profitability ratio always shall operate both in positive and negative diapasons of values. Negative $\mathrm{CFROI}^{\circledR}$ is a typical event at the initial stage of business development or at development of new market segments, reorganization and replacement of technologies. Furthermore, the economic efficiency has the capacity to be negative against financial difficulties, negative tendency development and solvency. Calculation ratio version is also convenient as it reflects the expenses incurred on capital and better provides the cash flow reinvestment possibilities.

Example: operating cash flow makes 20000 USD, and gross invested capital - 100000 USD. Service life of gross fixed assets totals 15 years, residual value of assets - 12000 USD, and capital expenditure ratio makes $10 \%$.

Economic depreciation amounts to 2769, 7 USD.

$$
\begin{gathered}
{\left[\frac{(100000-12000) x 0,1}{(1+0,1)^{15}-1}\right] .} \\
\text { CFROI }^{\circledR} \text { equals_ } 22,8 \%\left(\frac{-20000-2769,7}{100000}\right) .
\end{gathered}
$$

For the give case, IRR and MIRR give errors.

Now, we can move to more serious problem.

For the beginning, let's try to clear up the ratio calculation.

Example: the company's gross assets make 500 million USD, wherefrom the fixed assets total 250 million USD, and non-depreciable fixed assets (land parcels) equal 45 million USD. Furthermore, the company owns cash assets in the amount of 10 million USD and easily realizable securities. Stock of materials is evaluated at 25 million USD. Accordingly, gross non-depreciable assets make 80 million USD, and short-term current liabilities equal 35 million USD.

Net profit made 52 million USD, annual depreciation expense - 26 million USD, accumulated depreciation - 185 million USD, the tax rate prescribed by the Tax Code $-24 \%$, and interest payments -7 million USD. According to the data available on $\mathrm{R} \& \mathrm{D}$ expenditure for the past 4 years, the gross value of such expenditure made 17 million USD, capitalized operating lease - 23 million USD, and average weighted value of capital - 7\%.

Calculation of depreciable asset service life (according to accumulated depreciation expense):

$$
\text { Gross Plant Age }=185 / 26=7,11 \approx 7 \text { years }
$$

Fixed assets shall be calculated by the historical value.

Suppose that average inflation rate within this period made 1,097, i.e. prices increased by 1,91 .

Age of land parcels is ten years. After the last revaluation conducted 5 years ago, prices increased by 2,2.

Thus, the value of depreciated assets adjusted by inflation ratio makes 744,9 million USD $((250+185-45) \times 1,91)$, and the value of land parcels - 99 million USD $(45 \times 2,2)$.

Current assets are not required to be adjusted by inflation ratio.

Average age of fixed assets:

$$
\begin{aligned}
& \text { Asset Age }=(205 / 250) \times 7,11+(45 / 250) \times 10=7,63 \approx 8 \text { years. } \\
& \text { Gross investment: } \\
& \text { GI }=744,9+99+17+23=883,9 \text { million USD } \\
& \text { Gross cash flow: } \\
& \text { GCF }=52+7+26 \times(1-0,24)=78,76 \text { million USD } \\
& \quad \text { Salvage value: } \\
& \text { SV }=99+10+22=131 \text { million USD }
\end{aligned}
$$


Useful service life of depreciable assets (assessment made based on the age of fixed assets):

Asset Life $=(205+185) / 26=15$ years.

Determination of $\mathrm{CFROI}^{\circledR}$

Alternative 1.

\begin{tabular}{|c|c|c|c|c|}
\hline Time Period & Gross Investment & Gross Cash Flow & $\begin{array}{c}\text { Salvage Value of } \\
\text { Business }\end{array}$ & Cash Flow Scheme \\
\hline 0 & 883,9 & & & $-883,9$ \\
\hline 1 & & 78,76 & & 78,76 \\
\hline 2 & & 78,76 & & 78,76 \\
\hline 3 & & 78,76 & & 78,76 \\
\hline 4 & & 78,76 & & 78,76 \\
\hline 5 & & 78,76 & & 78,76 \\
\hline 6 & & 78,76 & & 78,76 \\
\hline 7 & & 78,76 & & 78,76 \\
\hline 8 & & 78,76 & & 78,76 \\
\hline 9 & & 78,76 & & 78,76 \\
\hline 10 & & 78,76 & & 78,76 \\
\hline 11 & & 78,76 & & 78,76 \\
\hline 12 & & 78,76 & & 78,76 \\
\hline 13 & & 78,76 & & 78,76 \\
\hline 14 & & 78,76 & & 78,76 \\
\hline 15 & & 78,76 & 131 & 209,76 \\
\hline CFROI $^{\circledR} \quad$ (IRR) & & & & $4,95 \%$ \\
\hline CFROI $^{\circledR}(\mathrm{MIRR}, 1$ & $\mathrm{f}=7 \%)$ & & & $5,97 \%$ \\
\hline
\end{tabular}

Alternative 2 .

Economic depreciation:

$$
\begin{gathered}
\mathrm{ED}=\frac{\text { GrossPlantxWACC}}{(1+W A C C)^{n}-1}=\frac{744,9 x 0,07}{1,07^{15}-1}=29,6 \text { million USD. } \\
\text { CFROI }^{\circledR}: \\
\text { CFROI }^{\circledR}=\frac{\text { GrossInvestment }- \text { SalvageValue }}{G I}=\frac{78,76-29,6}{883,9}=5,56 \% .
\end{gathered}
$$

All types of $\mathrm{CFROI}^{\circledR}$ settlement lead us to different results. In the given case, the advantage shall be given to the settlement under IRR, which equals 4,95\%. Whereas, this is in whole the result of profitability for the company, assumption about reinvestment as per the rate, which equals the capital value, won't work.

Note: changes caused by inflation ratio shall be charged only on the objects of Gross Plant, which is related to the fact that the asset age is calculated based on depreciation. And depreciation shall be charged only on long-term assets. Calculation of age shall not include the capitalized operating expense and goodwill, though it was possible to do so. Evaluation of current assets shall be provided by FIFO method. Accordingly, the inventory value shall be evaluated as per the last batch purchase price.

\section{CFROI ${ }^{\circledR}$ Interpretation}

Thus, the operating cash flows are repeated and reiterated, and therefore, it creates a necessary impression of the profit to be obtained from business in future. CFROI $^{\circledR}$ value shall be measured per annum. It may be modified or changed. Under current conditions, it's important to evaluate what kind of internal rate of return (IRR) applies to business. 
$\mathrm{CFROI}^{\circledR}$ has an analytical forecasting nature. This indicator requires special caution. If the asset operation life is 50 years, and according to calculations $\mathrm{CFROI}^{\circledR}$ makes $18 \%$, this does not mean that at the closure of business its profitability won't be $+30 \%$ or $-10 \%$. As practice shows, the operating cash flow is an unstable value. Business conditions may strongly change and the forecasting based on the cash flow efficiency will remain in the past. However, the only rational thing is that within each period of time it's useful to be aware of your company's, as the large investment project's profitability. Perhaps, you have plans with regard to business development and you can make a prognosis about how the cash flow efficiency will change in the nearest years, what will be the return rate (it mostly depends on realized investment projects). $\mathrm{CFROI}^{\circledR}$ shows stability of investment reserves. If the stability is low, we have to think about investment projects with a high NPV. If the profitability margin is high, we have to take all measures to maintain it at the same level. Mostly, it relates to the concept of total return of investment formed by the return of investment itself and the return on investments.

Finally, the essence of the company existence is to fully refund the funds invested therein and gain income in the amount that will cover alternative expense and bring profit to the company.

\section{References}

Brad, B., Joiner, M., Olsen, E. E., Stelter, D., \& Xhonneeux, P. (2002). Value Greators Report 2002: A Global Study of How Today's Top Corporations Can Generate Value Tomorrow-Succeed in Uncertain Times. Boston: Boston Consulting Group Report, 2002. http://www.bcg.com/publications/publications/files/Value_Creators_2002_Rpt_Dec02.pdf.

Damodaran, A. (2002). Investment Valuation ( $2^{\text {nd }}$ ed.). N.Y: John Wiley \& Sons.

Madden, B. J. (1999). CFROI Valuation, A Total System Approach to Valuing the Firm. Oxford: Butterworth-Heinemann.

Madden, B. J. (2000). CFROI ${ }^{\circledR}$ Valuation, Efficient Markets and Behavioral Finance. Oxford: Butterworth-Heinemann. www. LearninWhatWorks.com.

Madden, B. J. Maximizing Shareholder Value and The Greater Good $\left(1^{\text {st }}\right.$ ed.). www. LearninWhatWorks.com.

Obrycki, D. J., \& Resendes, R. (2001). Economic Margin: The Link Between EVA and CFROI. The Applied Finance Group, Ltd. http//www.economicmargin.com/PDF/EMwhitepaper.pdf.

Olsen E. E., Plaschke, F., \& Stelter, D. (2005). Balancing Act: Implementing an Integrated Strategy for Value Creation: The 2005 Value Creators Reports. Boston Consulting Group Report. http//www.bcg.com/publications/publications/files/Balancing_Act_an_INtegrated_Strategy_for_Value_Creation_N ov05.pdf.

Rawley, T. (2003). Value Management - Past, Present and Future. Life Cycle Returns, Inc.

Subramanian S., \& Bernstein, R. (2003). An Analysis of CFROI//Quantitive Viewpoint, \#27.

\section{(cc) $\mathrm{Br}$}

This work is licensed under a Creative Commons Attribution 3.0 License. 